\title{
Foreign Practices for Innovative Development of Regions: Application Prospects and Socio-Economic Consequences
}

Submitted 20/05/20, 1st revision 19/06/20, 2nd revision 11/07/20, accepted 30/07/20

\author{
V.A. Bondarenko ${ }^{1}$, A.A. Voronov ${ }^{2}$, A.A. Maksaev $^{3}$, N.V. Poluyanova ${ }^{4}$
}

\begin{abstract}
:
Purpose: The article considers the possibilities of combined use of foreign experience in innovative development of Russian regions, based on their current focus.

Design/Methodology/Approach: The article reveals practical positive results for the economic system related to the deepening of its innovative focus, provides examples of positive experience of innovative development in the USA, Europe, South Korea, China, provides the analysis of current innovative focus of the Russian economy, its regions' differentiation in terms of the severity of innovative development. The authors analyzed the difficulties in existing organizations' solutions.

Findings: Current positive experience of countries successfully pursuing the development of innovative economy, when evaluated and applied in Russian conditions, could contribute to the growth of innovative orientation of regional economies, affecting the improvement of Russia's overall position.

Practical implications: The authors propose the introduction of the combined experience of a number of countries that are successful in innovative development of the economy, to enhance the innovation emphasis of the Russian regions in terms of attracting local businesses to finance innovation, stepping up initiatives of the business and scientific communities localized in the regions, along with adaptive state support expressed primarily in promoting the rapid commercialization of innovation.

Originality/value: The authors' approach could become the basis for the development of an innovative focus in the economy of the Russian regions by initiating innovative local incentives further supported from the center and creating an innovative environment through the involvement of youth, initially focusing on innovative thinking and entrepreneurial activity.
\end{abstract}

Keywords: Innovative focus, regional economy, foreign experience, innovative development.

JEL codes: O11, O39.

Paper Type: Research Article

\footnotetext{
${ }^{1}$ Rostov State University of Economics, Rostov-on-Don, Russian Federation, email:

b14v@yandex.ru

${ }^{2}$ Krasnodar branch of Plekhanov Russian University of Economics, Krasnodar, Russian Federation.

${ }^{3}$ Krasnodar Cooperation Institute, Krasnodar, Russian Federation

${ }^{4}$ Belgorod National Research University, Belgorod, Russian Federation.
} 


\section{Introduction}

National socio-economic policy of Russia and, accordingly, its socio-economic policy in the regions are focused on innovative development, which is confirmed by the adoption of relevant official documents (EDIE, 2019) as well as striving by the need to occupy a worthy position in the national economy global market for innovative products and services. Such an orientation finds theoretical justification in the perception of knowledge as the basis of innovation, a key component of the progressive and sustainable development of the regional economy (Toffler and Toffler, 2006).

Economists and academics note that improving the quality of life of the population, along with increasing international competitiveness for the state, could be achieved through innovative business activity encouraged at the state level (Porter, 1998). Modern experts substantiate the point that about $60 \%$ of the profit received by a business falls on the share of innovative goods and services (Kim and Mauborgne, 2015). As a part of the practical refraction of this issue, we emphasize that today the expert community, assessing the socio-economic development of the country and its regions, does not proceed from the economic indicators themselves, but validates the possibility of creating, developing, promoting innovative developments (Govorova, 2019; Sachpazidu-Wojcicka, 2020).

Nevertheless, certain difficulties arise on the way to the innovative development of the economy of Russia and its regions. In the total volume of goods shipped, the share of innovative products is no more than $1.3 \%$, while in the Netherlands this indicator is manifested at the level of $6.6 \%$, and in the UK at the level of $8.8 \%$ (Indicators of innovative activity, 2018). For comparison, one can also indicate that Rosneft's costs for internal research and development account for about $0.2 \%$ of the costs for these goals of the foreign Samsung company (Golova and Suhovey, 2019). In terms of the ratio of $R \& D$ expenditures to sales, the Russian company Kamaz lags significantly behind the foreign Volkswagen (this figure for Kamaz is $1.6 \%$, while for Volkswagen is $5.7 \%$ ) (Golova and Suhovey, 2019).

Such a statement makes it reasonable to study the experience of foreign countries in terms of organizing innovative activities and focusing on the innovative development of the national economy and regions in order to look for ways to break their positive achievements in Russian reality.

\section{Materials and Methods}

As part of a study of foreign experience in organizing innovative activities and the focus of economies on innovative development, the article analyzes the decisions made in the framework of the implementation of the European Union's innovation policy regarding the development strategy "Europe 2020", the study of the main 
models for the development of regional systems, innovative activities in Japan, China and the United States, as well as using statistical data, provides an analysis of the situation in Russia and its regions in terms of implementing innovative economic development.

\section{Results and Discussion}

Analyzing the current world experience in innovative economics development, we note that Suslov (2012) emphasizes the representativeness of the three basic models of constructed innovative systems, which form the basis of the efforts. The author notes that success in the American version of the innovative development model is ensured by involving venture capital and an emphasis on supporting basic research, the education sector and small business with a minimum degree of direct regulation of the state.

In the European model, according to the author, the participation of the state and technological platforms created under his auspices predominate, combining the efforts of government agencies, investors, industrial companies, and the scientific and educational sector. Despite the support of the state, development is realized through the activity of business, production, science, and goes from the bottom up to the principle of formulating initiatives and their support.

In the framework of the Asian model, mainly the Chinese one, we are also talking about combining the efforts of the state, science and business in the framework of focusing on a synergistic effect, however, initiatives are fully formed at the top and centrally descend to the level of regions and subjects involved in solving innovative initiatives (Suslov, 2012).

Kolesnikova (2012) characterizing the reasons for success in the innovative development of China, which is the second largest economy in the world in terms of GDP, speaks of attracting external investors and technology companies while reducing the available preferences for external players to redistribute them to domestic technological leaders.

Japan combines the leading role of the state with active investment in the development of innovation by business. The existing ratio is $80 \%$ of private investments and $20 \%$ are from the state. Japanese experience includes the formation of a model of national technology parks. This techno platform is a collaboration of science and production.

The state assumes the role of a conduit for the rapid commercialization of innovations (Malyutin, 2013). Cherkasov (2013) notes that the USA implements an initiative, according to which, with the commitments undertaken by business to create new jobs in an innovative enterprise, the state, free of charge or for a nominal fee, transfers the 
results of $R \& D$ to an entrepreneur who is further involved in the innovative development of his localization.

In Europe, successful innovative companies are supported by financing from the state budget, while in Korea benefits are given to innovative businesses that produce technological innovations within the framework of certain priority technologies. Vermel (2013) describes the picture in the innovation sector as follows: in foreign practice, the drivers of innovation investments are large international corporations, which account for up to $70 \%$ of total investment in innovations. However, these large structures in the regions interact with small innovative enterprises that are more flexible and easier to adapt to changing conditions and needs, which stimulates innovative development in the regions.

In European countries, within the framework of the Europe 2020 strategy and the Horizon 2020 program, priorities are set for technologies such as eco, nano, bio, information systems, which contributes to economic development while focusing on solving social problems (Salamatina, 2017). The innovative orientation of production in the EU is more than $75 \%$. On average, GDP per capita is 2.5 times higher than in Russia, which, in many respects, is associated with innovative economic development (Information review of the new framework program, 2020).

In the framework of innovation development priorities, issues regarding climate change, energy efficiency, resource efficiency, health care and demography, as well as improving the conditions for access to financing innovative developments aimed at economic growth and employment, arise (Taranov, 2016). In the EU, technology, and research programs, as well as national programs for creating innovative clusters and programs aimed at commercializing the results of $\mathrm{R} \& \mathrm{D}$, are actively used on behalf of the state to activate the R\&D sector. Characterizing the position of Russia in the global ranking of the global innovation index in comparison with other countries that are more successful in this area, we note that it is ranked only 46th, significantly inferior to China, South Korea, the United States, and EU countries (Figure 1).

It can be noted that during the indicated time interval, for example, Israel and India significantly improved their positions However, the ranks of Russia were still modest. It should also be noted that Russia's leading manufacturing companies are significantly inferior in terms of investment in research and development to foreign high-tech companies in terms of these indicators (Figure 2).

Naturally, the current situation complicates the innovative development of the Russian economy. For example, all the costs of research and development in Russia from all sources, based on official statistics, amounted to about 14.3 billion euros, which is comparable to the costs of one large company from South Korea and less than the total expenses of two software companies in the United States (Golova and Suhovey, 2019). 
Figure 1. Rankings of countries in the global innovation index (GII) in 2015 and 2018 (GII2015, 2016; GII2018, 2019).

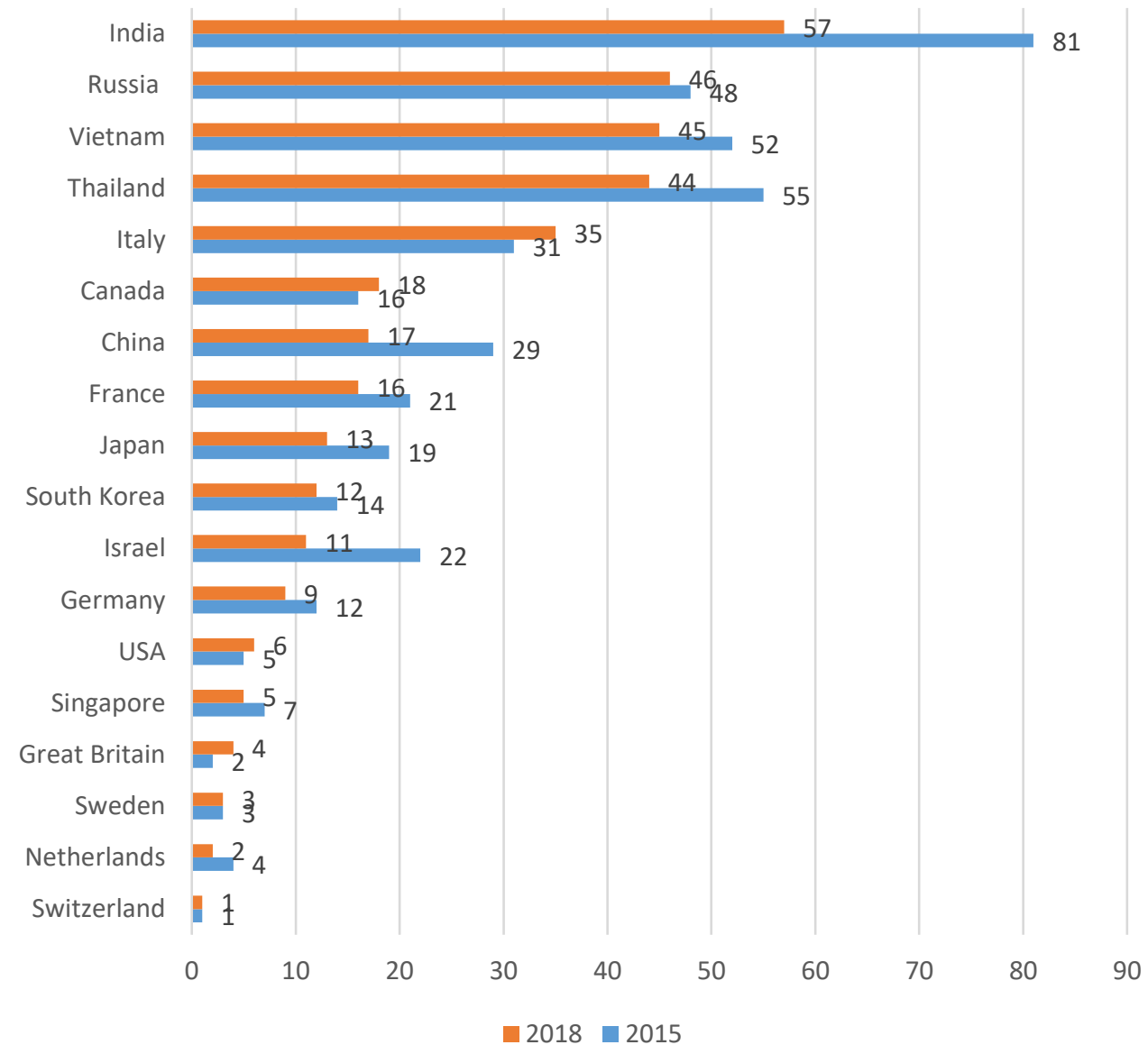

Source: Authors.

According to the national project "Science", domestic R\&D expenditures in Russia should increase by 2024 to 1.8 billion rubles (Passport of the national project "Science", 2018). However, according to expert estimates, an additional 2-3 times increase in funding is needed to address the ambitious challenges facing the Russian economy and science (Golova and Suhovey, 2019).

Based on expert estimates, the following data on the distribution of Russian regions according to their innovation activity could be given in Figure 3. The leading regions include St. Petersburg, the Republic of Tatarstan, Moscow, Tomsk, Moscow, Novosibirsk, Kaluga and Nizhny Novgorod regions. 
Figure 2. Research and development costs of leading companies from around the world in 2018 (EURnD, 2019).

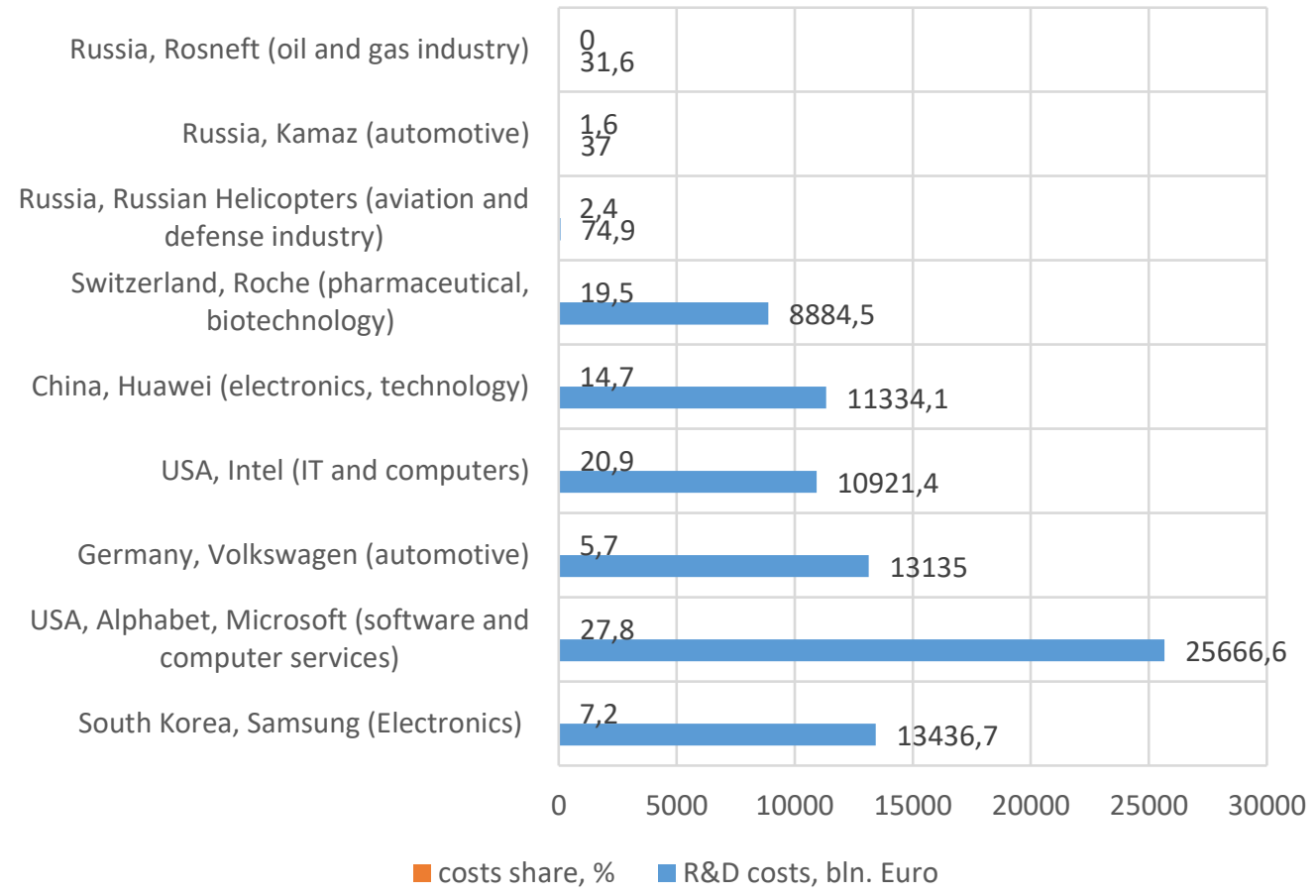

Source: Authors.

Figure 3. Differentiation of Russian regions according to innovation activity (RIR, 2019)

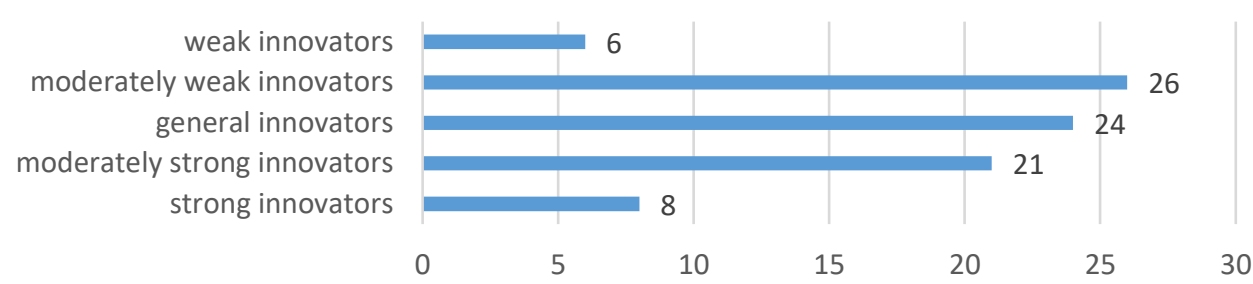

Source: Authors.

According to the methodology for assessing Russian regions in identifying priority areas for the formation of innovative infrastructure on their territory, the following 10 regions are leading (Figure 4). It is advisable to pay attention that in this case, when evaluating according to the mentioned criterion, the 8 leaders are added to the Perm Territory, Samara and Sverdlovsk Region, and the Novosibirsk Region is dropped out of their list. 
Figure 4. Regions of Russia leading in priority in the formation of elements of the innovation system in 2005 and 2017 (Golova and, Suhovey, 2019)

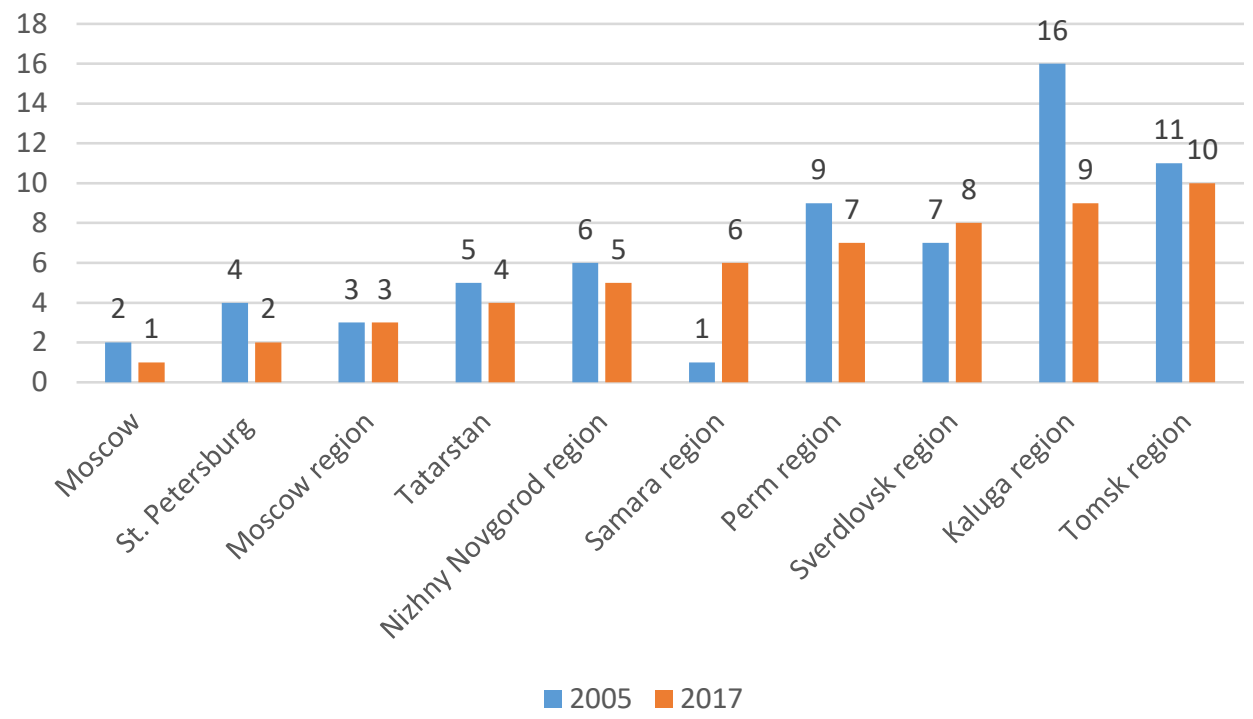

Source: Authors.

Notable that the difficulties in the development of an innovative economy in comparison with foreign economic systems are manifested throughout the country. They are peculiar to these leading regions and are hypertrophied in regions with a weak general innovative focus.

In our opinion, to increase the financing of science and innovations, it is not enough to justify the existing situation, especially since the implementation of such an initiative by force, mainly from the state, seems difficult, especially on the scale of socio-economic development of all regions.

\section{Conclusion}

It seems reasonable to us to use the combined experience of other countries that are successful in implementing the trajectory of innovative development. It is advisable to take the experience of European countries as a basis, which is already being done in terms of creating a technological platform and territorial innovation clusters. As part of this focus, research and educational centers are being formed in several regions of Russia to become integrators of the creation of scientific developments jointly by industrial companies, investment companies and research and educational institutions.

However, it is stated that scientific, educational and propaganda work should be carried out among young people, initially focusing on innovative thinking and entrepreneurial activity now and in the future. This will make it possible, similarly to 
the European model, to find innovation development centers "from below" and to provide assistance and support to these initiatives in the regions instead of the idea of planting innovative "from above". With this approach, an innovative infrastructure will be formed where such a request has appeared, and not because of possible voluntarist decisions.

Entrepreneurial initiatives in society, in general, will facilitate the involvement of business in more active financing of innovations, instead of the current dominance of a state funding source. The role of the state, similarly to the foreign practices, for example, Japan, should be more widely traced in terms of promoting the commercialization of innovations. It is also justified to use the US experience in helping small and medium-sized businesses in the regions to transfer to them for a nominal fee the results of $R \& D$, if they create new jobs in the region. We believe that the proposed measures will contribute to the innovative development of Russian regions.

\section{References:}

Cherkasov, M.N. 2013. Analysis of world experience in stimulating scientific, technical and innovative activity. Almanac of modern science and education, 1, 161-165.

EDIE. 2019. State program of the Russian Federation 'Economic development and innovative economy'. Available at: https://www.economy.gov.ru/material/dokumenty/postanovlenie_pravitelstva_rf_ot_1 5_aprelya_2014_g_n_316.html.

EURnD. 2019. The 2018 EU Industrial R\&D Investment Scoreboard. Data World 2500, European Commission, available at: http://iri.jrc.ec.europa.eu/118.

GII2015. 2016. The Global Innovation Index 2015: Effective Innovation Policies for Development. Available at: www.globalinnovationindex.org/about-gii\#reports.

GII2018. 2019. The Global Innovation Index 2018: Energizing the World with Innovation. Available at: www.globalinnovationindex.org/about-gii\#reports.

Golova, I.M., Suhovey, A.F. 2019. Differentiation of innovation development strategies taking into account the specifics of Russian regions. Regional Economy, 4(15), 12941308.

Govorova, N. 2019. Industrial policy in the EU. Scientific and Analytical Bulletin of the IE RAS, 1, 108-113.

Horizon. 2014. Information review of the new European Union framework program for scientific, technological and innovative development "Horizon 2020". Available at: http://ncp.tsagi.ru/horizon2020/upload/doc1.pdf.

IIA. 2018. Indicators of innovation activity. Moscow, HSE, 332.

Kim, W.Ch., Mauborgne, R. 2015. Blue Ocean Strategy. Harvard Business School Press, London, 316.

Kolesnikova, T.V. 2012. Innovative component of the Chinese economy. Economic Journal, 4, 31-39.

Malyutin, D.L. 2013. Traditions and rationality: analysis and evaluation of the formation of the innovative environment in Japan. Creative Economy, 5, 65-69.

NP. 2018. Passport of the national project "Science". Available at: http://government.ru/projects/ selection / 740/35565 /. 
Porter, M. 1998. Competitive Strategy: Techniques for Analyzing Industries and Competitors. The Free Press, New York.

RIR. 2019. Rating of innovative regions of Russia. Available at: https://4science.ru/articles/Reiting-innovacionnih-regionov-Rossii.

Sachpazidu-Wojcicka, K. 2020. Open innovation process via technology transfer and organizational innovation. European Research Studies Journal, 23(1), 52-61, DOI: $10.35808 /$ ersj/1535.

Salamatina, S.Yu. 2017. Analysis of the European experience of innovative development of the national economy. Tauride scientific observer, 3, 193-199.

Suslov, V.I. 2012. Synergy of regional innovation systems. Innovations, 1, 11-14.

Taranov, P.M. 2016. Scientific and methodological aspects of the feasibility study of innovative projects at the present stage. Economics and Entrepreneurship, 10(2), 510514.

Toffler, A., Toffler, H. 2006. Revolutionary Health. Knopf, 512.

Vermel. M.V. 2013. Basic types of organization of the national innovation economic system on the example of developed countries. Creative Economy, 5, 22-34. 